\title{
Turbot reovirus (SMReV) genome encoding a FAST protein with a non-AUG start site
}

\author{
Fei Ke, Li-Bo He, Chao Pei and Qi-Ya Zhang*
}

\begin{abstract}
Background: A virus was isolated from diseased turbot Scophthalmus maximus in China. Biophysical and biochemical assays, electron microscopy, and genome electrophoresis revealed that the virus belonged to the genus Aquareovirus, and was named Scophthalmus maximus reovirus (SMReV). To the best of our knowledge, no complete sequence of an aquareovirus from marine fish has been determined. Therefore, the complete characterization and analysis of the genome of this novel aquareovirus will facilitate further understanding of the taxonomic distribution of aquareovirus species and the molecular mechanism of its pathogenesis.

Results: The full-length genome sequences of SMReV were determined. It comprises eleven dsRNA segments covering 24,042 base pairs and has the largest $\$ 4$ genome segment in the sequenced aquareoviruses. Sequence analysis showed that all of the segments contained six conserved nucleotides at the $5^{\prime}$ end and five conserved nucleotides at the $3^{\prime}$ end (5'-GUUUUA - - UCAUC-3'). The encoded amino acid sequences share the highest sequence identities with the respective proteins of aquareoviruses in species group Aquareovirus A. Phylogenetic analysis based on the major outer capsid protein VP7 and RNA-dependent RNA polymerase were performed. Members in Aquareovirus were clustered in two groups, one from fresh water fish and the other from marine fish. Furthermore, a fusion associated small transmembrane (FAST) protein NS22, which is translated from a non-AUG start site, was identified in the S7 segment.

Conclusions: This study has provided the complete genome sequence of a novel isolated aquareovirus from marine fish. Amino acids comparison and phylogenetic analysis suggested that SMReV was a new aquareovirus in the species group Aquareovirus A. Phylogenetic analysis among aquareoviruses revealed that VP7 could be used as a reference to divide the aquareovirus from hosts in fresh water or marine. In addition, a FAST protein with a nonAUG start site was identified, which partially contributed to the cytopathic effect caused by the virus infection. These results provide new insights into the virus-host and virus-environment interactions.
\end{abstract}

\section{Background}

Aquareoviruses have been isolated from a wide variety of aquatic animals [1,2]. These viruses represent a great threat to the aquaculture industry in China and East Asia. As a genus of the family Reoviridae, viruses in Aquareovirus have eleven-segmented dsRNA genomes. The virus particles are icosahedral in symmetry and have a double-layered capsid. Aquareoviruses have been divided into seven species (aquareovirus A to G, AQRVA to $\mathrm{G}$ ) according to RNA-RNA blot hybridization or sequence comparison [3,4]. There are three aquareoviruses that have complete sequence information: Grass

\footnotetext{
* Correspondence: zhangqy@ihb.ac.cn

State Key Laboratory of Freshwater Ecology and Biotechnology, Institute of Hydrobiology, Chinese Academy of Sciences, Wuhan 430072, China
}

carp reovirus (GCRV, species AQRV-C), Golden shiner reovirus (GSRV, species AQRV-C), and American grass carp reovirus (AGCRV, species AQRV-G) [4-6]. In addition, nearly complete sequence data was available for Chum salmon reovirus (CHSRV, species AQRV-A) except for segment 4. Additionally, some other aquareoviruses have sequence information for parts of the genome segments. However, sequence and molecular data seems to be insufficient for comparing species in Orthoreovirus, which was considered as the most related genus with Aquareovirus [6].

The family Reoviridae contains fifteen genera of reoviruses with $9,10,11$ or 12 dsRNA genome segments [4]. Members in Orthoreovirus (except MRV) and Aquareovirus make up the fusogenic reovirus, whose infection
C Biomed Central

() 2011 Ke et al; licensee BioMed Central Ltd. This is an Open Access article distributed under the terms of the Creative Commons Attribution License (http://creativecommons.org/licenses/by/2.0), which permits unrestricted use, distribution, and reproduction in any medium, provided the original work is properly cited. 
causes cell-cell fusion and the formation of a syncytium $[7,8]$. Up to now, the nonstructural fusion associated small transmembrane (FAST) proteins represent the only known nonstructural viral proteins that induce cell-cell fusion; however, they are not directly related to virus entry or exit. A number of FAST proteins have been identified in orthoreovirus and aquareovirus species, and the protein topology, structural motifs, and some key amino acids have also been identified [9-12]. Thus, the identification of new FAST proteins would help to the further elucidate their functions.

The only reported aquareovirus in China was grass carp reovirus (GCRV), which was isolated from freshwater grass carp. Recently, a Scophthalmus maximus reovirus (SMReV) was isolated and identified from a diseased turbot. It is the first isolated aquareovirus from a marine fish in China. The complete genome sequence of SMReV was determined and compared with other reoviruses. Sequence and functional analysis also identified a FAST protein that utilized a non-AUG translation start site.

\section{Results}

\section{Pathology, morphology, and the genome of SMReV}

SMReV could cause a cytopathic effect (CPE) in Grass carp fins (GCF) and in Chinook salmon embryo (CHSE) cell lines after 4-5 days incubation. The optimal temperature was $20^{\circ} \mathrm{C}$. The CPE contained several separate plaques in which syncytia formed (Figure 1A).

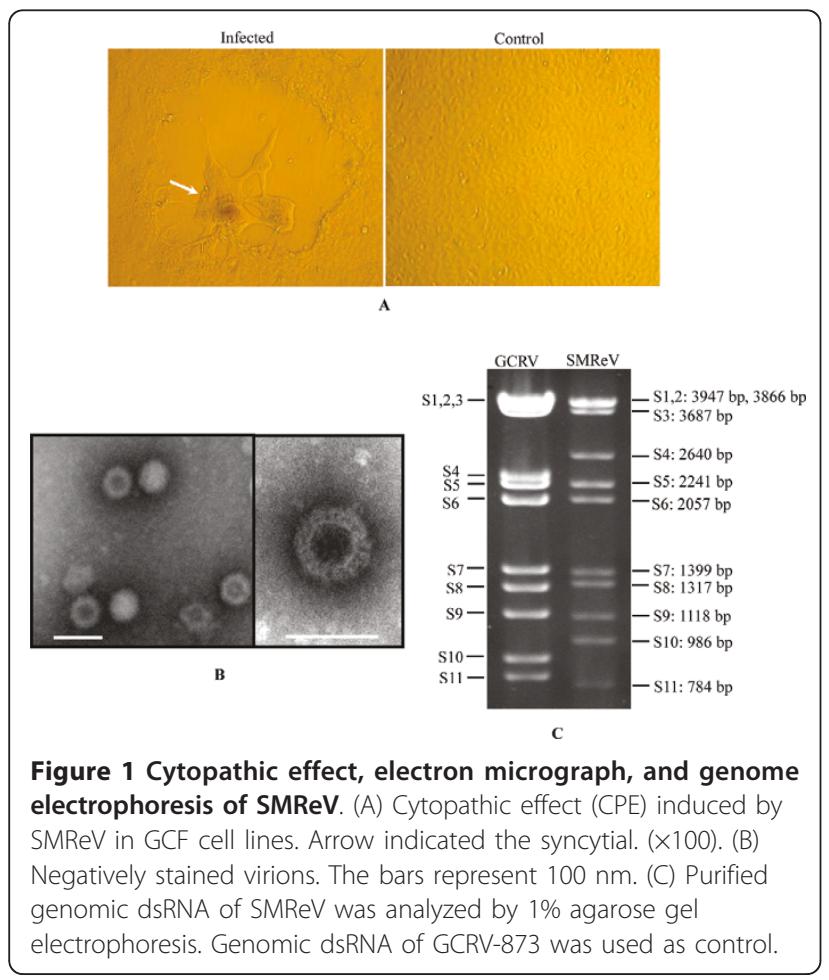

Electron microscopy observations showed that the negatively stained virions had the typical morphology of aquareoviruses, including an inner nucleocapsid surrounded by double-layered capsids, and were about 70$80 \mathrm{~nm}$ in diameter (Figure 1B). The biophysical and biochemical properties of $\mathrm{SMReV}$ included resistance to heat, acid ( $\mathrm{PH} \mathrm{3.0)}$, and alkaline (PH11.0) treatment. Treatment with chloroform or 5-iodo-2'-deoxyuridine (IUdR, Sigma) did not affect the viral infectivity.

The SMReV genomes were purified and analyzed by $1 \%$ agarose gel electrophoresis. As shown in Figure $1 \mathrm{C}$, the genome segments were separated into 10 distinct bands, with segments 1 and 2 comigrating. Comparison with the genome of GCRV-873 showed that migration of SMReV genome segments was different from those of GCRV.

The complete sequences of segments 1-11 of SMReV were obtained and have been deposited in GenBank under accession numbers HM989930-HM989940. The lengths of SMReV genome segments ranged from 784 (S11) to 3947 (S1) bp, with a total of 24042 bp (Table 1).

\section{Non-coding regions of SMReV genome segments}

As shown in Table 1, the lengths of SMReV non-coding regions ranged from 12 to 28 nucleotides at the $5^{\prime}$ end and ranged from 27 to 162 nucleotides at the 3' end. The S4 genome segment had a non-coding region as long as 162 nucleotides at the 3' end, which was longer than the corresponding segment any other aquareoviruses so far sequenced.

Conserved terminal nucleotide sequences have been considered as a feature in reovirus classification. Comparison of the genome sequences of SMReV showed that all of the segments had conserved terminal sequences. The conserved nucleotides 5'-GUUUUA ${ }^{\mathrm{U}} / \mathrm{G} /$ A-3' were present at the 5 ' ends in all the positive strands of each segment and 5'- ${ }^{2} \mathrm{~A} / \mathrm{A} U C A U C-3$ ' was present at the 3' end. They were very similar to those of CHSRV (AQRV-A) (5'-GUUUUA ${ }^{\mathrm{U}} / \mathrm{G}^{-} 3^{\prime}$ at $5^{\prime}$ end and $5{ }^{\prime}-\mathrm{U} / \mathrm{A} / \mathrm{A} U C A U C-3$ ' at 3 ' end) and AGCRV (AQRV-G) (5'-GUUUUA ${ }^{\mathrm{U}} / \mathrm{A}^{-}-3^{\prime}$ at 5 ' end and $\mathrm{U} / \mathrm{A} / \mathrm{C}$ U/A UCAUC-3' at 3 ' end) (Table 2). However, there were some differences between SMReV and species in AQRV-C (GCRV873 and GSRV, 5'-GUUAUU ${ }^{\mathrm{U}} / \mathrm{G}^{-} 3^{\prime}$ at $5^{\prime}$ end and $5^{\prime}-\mathrm{U} /$ A UCAUC-3' at 3' end). Interestingly, a newly isolated aquareovirus from grass carp showed a distinct terminal sequence at 5' end (GCRV HZ08, 5'-GUAAUU-3') [13]. Conserved terminal sequences could be used in genome assembly and packaging as "sorting" signals [14].

Moreover, the first and last nucleotides of each segment in all aquareoviruses were complementary (G-C). Potential imperfect inverted repeats were also predicted in the sequences adjacent to each termini of the SMReV positive-sense strand (Figure 2). It had been reported that complementary sequences in the 5' and 3' NCR 
Table 1 Characteristics of genome segments and predicted functions of proteins in SMReV

\begin{tabular}{|c|c|c|c|c|c|c|c|c|c|c|}
\hline \multirow[b]{2}{*}{$\begin{array}{l}\text { Genome } \\
\text { segment }\end{array}$} & \multicolumn{5}{|l|}{ Gene } & \multicolumn{4}{|l|}{ Protein } & \multirow[t]{2}{*}{ Predicted function } \\
\hline & $\begin{array}{l}\text { Segment } \\
\text { length } \\
\text { (bp) }\end{array}$ & GC\% & $\begin{array}{l}5^{\prime} \text { UTR } \\
\text { (bp) }\end{array}$ & $\begin{array}{l}\text { 3'UTR } \\
\text { (bp) }\end{array}$ & $\begin{array}{l}\text { Nucleotide } \\
\text { position of } \\
\text { ORF }\end{array}$ & $\begin{array}{l}\text { Coding } \\
\text { potential }\end{array}$ & $\begin{array}{l}\text { Protein } \\
\text { size } \\
\text { (aa) }\end{array}$ & $\begin{array}{l}\mathrm{MM} \\
\text { (KDa) }\end{array}$ & $\begin{array}{l}\text { Isoelectric } \\
\text { point }(\mathrm{pl})\end{array}$ & \\
\hline S1 & 3947 & 54.32 & 13 & 40 & $14-3907$ & VP1 & 1297 & 141.4 & 6.13 & Core protein, capping enzyme \\
\hline S2 & 3866 & 54.86 & 12 & 29 & $13-3837$ & VP2 & 1274 & 140.97 & 8.39 & Core protein, polymerase \\
\hline S3 & 3687 & 55.19 & 18 & 39 & $19-3648$ & VP3 & 1209 & 131.10 & 6.10 & Core protein, Helicase, NTPase \\
\hline S4 & 2640 & 57.54 & 24 & 162 & $25-2478$ & NS88 & 817 & 87.80 & 6.18 & $\begin{array}{l}\text { Nonstructural protein, involved in the } \\
\text { formation of viral inclusion bodies with } \\
\text { NS38 }\end{array}$ \\
\hline S5 & 2241 & 53.59 & 21 & 27 & $22-2214$ & VP4 & 730 & 80.52 & 7.23 & NTPase \\
\hline S6 & 2057 & 54.93 & 28 & 67 & 29-1990 & VP5 & 653 & 69.25 & 4.69 & Outer capsid \\
\hline \multirow[t]{2}{*}{ S7 } & 1399 & 54.82 & 16 & 74 & $17-613$ & NS22 & 198 & 22.15 & 8.93 & FAST protein \\
\hline & & & & & 489-1325 & NS32 & 278 & 31.81 & 6.16 & Nonstructural protein \\
\hline S8 & 1317 & 55.50 & 12 & 51 & $13-1266$ & VP6 & 417 & 45.18 & 8.91 & Core protein \\
\hline S9 & 1118 & 56.26 & 25 & 40 & $26-1078$ & NS38 & 350 & 38.12 & 6.60 & $\begin{array}{l}\text { Nonstructural protein, involved in } \\
\text { formation of viral inclusion bodies with } \\
\text { NS88 }\end{array}$ \\
\hline S10 & 986 & 56.80 & 27 & 62 & $28-924$ & VP7 & 298 & 32.18 & 7.56 & Outer capsid \\
\hline S11 & 784 & 56.63 & 24 & 52 & $25-732$ & NS25 & 235 & 25.32 & 7.88 & Nonstructural protein \\
\hline
\end{tabular}

could facilitate viral replication by circularizing the RNA transcript [15].

Proteins encoded by genome segments S1-S6 and S8-S11 The S1 genome segment of SMReV was predicted to encode the core spike protein VP1, which functions as the mRNA capping enzyme. Four conserved amino acids, two lysines and two histidines, were found in the N-terminus of VP1 (lysine 176 and 196, histidine 229 and 238). The VP1 proteins of SMReV and GCRV shared a sequence identity of $44 \%$ (table 2) and were highly similar in their hydrophobic profiles.

Table 2 Conserved terminal nucleotide sequences and percent sequence identities of genome segments and proteins between SMReV and other aquareovirus and orthoreovirus species

\begin{tabular}{|c|c|c|c|c|c|c|c|c|c|c|c|c|c|c|c|c|c|c|c|c|c|c|c|c|}
\hline & & S1 & & $\mathrm{S} 2$ & & S3 & & S4 & & $\mathrm{S} 5$ & & S6 & & S7 & & 58 & & S9 & & $\mathrm{S} 10$ & & S11 & & Conserved terminal \\
\hline & & $\mathrm{nt}$ & aa & $\mathrm{nt}$ & aа & $\mathrm{nt}$ & aa & $\mathrm{nt}$ & aa & $\mathrm{nt}$ & aа & $\mathrm{nt}$ & & $\mathrm{nt}$ & aa & $\mathrm{nt}$ & aa & $\mathrm{nt}$ & aa & $\mathrm{nt}$ & aа & $\mathrm{nt}$ & aа & \\
\hline \multirow[t]{5}{*}{ AQRV-A } & CHSRV & 74 & 84 & 79 & 93 & 79 & 85 & - & - & 72 & 80 & 75 & 85 & 74 & 61,50 & 79 & 88 & 78 & 85 & 71 & 76 & 83 & - & $5^{\prime}-G \cup \cup \cup \cup A \ldots . . . . \cup C A \cup C-3^{\prime}$ \\
\hline & TFRV & - & - & - & - & - & - & - & - & - & - & 77 & 91 & - & - & - & - & - & - & 77 & 84 & 84 & 86 & $5^{\prime}-G \cup \cup \cup \cup A \ldots . . . . \cup C A \cup C-3^{\prime}$ \\
\hline & SBRV & - & - & - & - & - & - & - & - & - & - & - & - & - & - & 78 & 86 & - & - & 77 & 84 & - & - & 5'-GUUUUA....... UCAUC-3' \\
\hline & $\begin{array}{l}\text { ASRV- } \\
\text { TS }\end{array}$ & - & - & 79 & 94 & - & - & - & - & - & - & - & - & - & - & - & - & - & - & 73 & 78 & - & - & 5'-GUUUUA...... UCAUC-3' \\
\hline & $\begin{array}{l}\text { ASRV- } \\
2009\end{array}$ & - & - & - & - & - & - & - & - & - & - & - & - & 78 & 73,76 & - & - & - & - & 77 & 84 & - & - & $5^{\prime}-G \cup \cup \cup \cup A . . . . . \cup C A \cup C-3^{\prime}$ \\
\hline \multirow[t]{2}{*}{ AQRV-C } & $\begin{array}{l}\text { GCRV- } \\
873\end{array}$ & 55 & 44 & 60 & 59 & 57 & 52 & 13 & 26 & 17 & 35 & 57 & 53 & 3 & 23,20 & 36 & 44 & 54 & 41 & 5 & 13 & 3 & 19 & 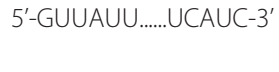 \\
\hline & GSRV & 56 & 44 & 60 & 59 & 58 & 52 & 13 & 26 & 17 & 35 & 60 & 53 & 3 & 25,21 & 38 & 45 & 54 & 41 & 5 & 13 & 5 & 20 & 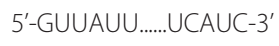 \\
\hline \multirow[t]{2}{*}{ AQRV-G } & AGCRV & 52 & 44 & 60 & 58 & 57 & 53 & 13 & 23 & 10 & 35 & 56 & 51 & 5 & 21,26 & 38 & 40 & 25 & 37 & 8 & 17 & 7 & 23 & 5'-GUUUUA....... UCAUC-3' \\
\hline & $\begin{array}{l}\text { GCRV- } \\
\text { HZ08 }\end{array}$ & 6 & 30 & 37 & 42 & 9 & 34 & - & - & 2 & 22 & 4 & 29 & - & - & - & - & - & - & - & - & - & - & $5^{\prime}-\mathrm{G} \cup A A \cup \cup \ldots . . . . \cup C A \cup C-3^{\prime}$ \\
\hline \multirow[t]{4}{*}{ Orthoreovirus } & MRV-1 & 5 & 25 & 28 & 40 & 7 & 31 & 2 & 12 & 2 & 17 & 3 & 25 & 2 & $\mathrm{NE}, 8$ & 2 & 22 & 2 & 11 & 3 & 8 & $\mathrm{NE}$ & $\mathrm{NE}$ & $5^{\prime}-\mathrm{GCUA} \ldots \ldots \ldots . . . . \cup \mathrm{U} A \cup C-3^{\prime}$ \\
\hline & MRV-2 & 3 & 24 & 24 & 40 & 3 & 31 & 1 & 13 & 2 & 18 & 4 & 25 & 2 & $\mathrm{NE}, 8$ & 1 & 19 & 2 & 13 & 3 & 8 & $\mathrm{NE}$ & $\mathrm{NE}$ & $5^{\prime}-\mathrm{GCUA} \ldots \ldots \ldots . . . . \cup \mathrm{U} A \cup C-3^{\prime}$ \\
\hline & MRV-3 & 2 & 25 & 28 & 40 & 12 & 31 & 1 & 12 & 2 & 17 & 3 & 25 & 2 & $\mathrm{NE}, 4$ & 2 & 20 & 3 & 11 & 3 & 8 & $\mathrm{NE}$ & $\mathrm{NE}$ & $5^{\prime}-G C U A \ldots \ldots . . . . . \cup C A \cup C-3^{\prime}$ \\
\hline & $\begin{array}{l}\text { ARV } \\
\text { S1133 }\end{array}$ & 4 & 24 & 24 & 41 & 7 & 30 & 3 & 16 & 2 & 16 & 6 & 23 & 1 & 6,5 & 2 & 17 & 3 & 13 & 3 & 9 & $\mathrm{NE}$ & NE & $5^{\prime}-\mathrm{GCUUUU} . . . . . . \cup C A \cup C-3^{\prime}$ \\
\hline
\end{tabular}

nt: nucleotide sequence.

aa: amino acid sequence.

"-": complete sequence not available.

NE: no equivalent sequence.

Abbreviations: CHSRV: Chum salmon reovirus; TFRV: Threadfin reovirus; SBRV: Striped bass reovirus; ASRV-TS: Atlantic salmon reovirus TS; ASRV-2009: Atlantic salmon reovirus 2009; GCRV-873: Grass carp reovirus 873; GSRV: Golden shiner reovirus; AGCRV: American grass carp reovirus; GCRV-HZ08: Grass carp reovirus HZ08; MRV-1: Mammalian orthoreovirus 1; MRV-2: Mammalian orthoreovirus 2; MRV-3: Mammalian orthoreovirus 3; ARV S1133: Avian orthoreovirus S1133. 


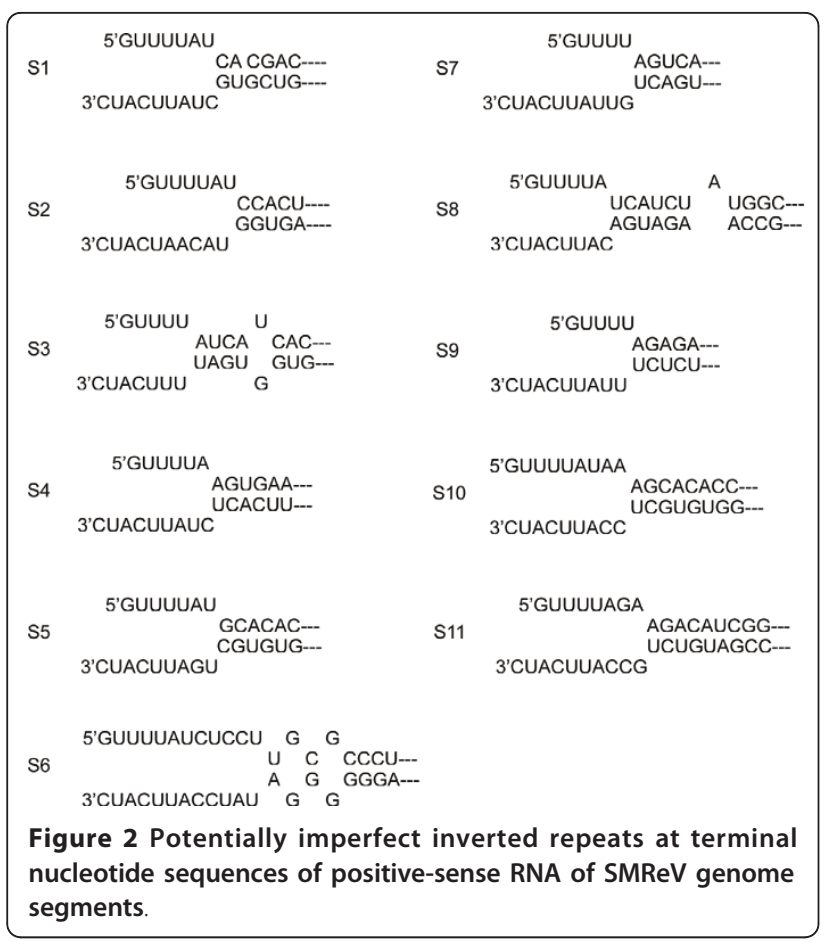

The S2 genome segment of SMReV was predicted to encode the core protein VP2, which is an RNA-dependent RNA polymerase (RdRp). The catalytic domain of RdRp was identified between amino acids 550 and 798 in VP2 by motifscan (ExPASy proteomics server). Previous research had identified five important motifs, motif A, B, C, D and E, in RdRp [16]. Motif A (DXXXXD, 591-596), motif B (SG, 648-649), and motif C (GDD, 739-741) were found in the predicted catalytic domain of SMReV VP2. Amino acid alignments revealed that these motifs are also conserved in the RdRp proteins of Aquareovirus and Orthoreovirus species. Moreover, a hydrophobic region was identified in the Cterminus of SMReV VP2 that could be motif E of RdRp.

The S3 genome segment of SMReV was predicted to encode the core protein VP3, which functions as a helicase and NTPase. A zinc finger $\mathrm{C} 2 \mathrm{H} 2$ domain was identified in the SMReV VP3 at amino acid positions 113136, which is known to bind RNA. As revealed by CryoEM analysis, amino acids Glu502, Ser503, Thr504, and Thr505 are involved in RNA transcription in GCRV [17]. Amino acid alignments showed that the four amino acids were conserved in MRV, GCRV, GSRV, and AGCRV. However, the corresponding amino acids were Glu, Thr, Thr, and Thr in SMReV and CHSRV.

The S4 genome segment was predicted to encode the nonstructural protein NS88. This segment was larger than its homologs in other Aquareovirus species. The high percentage of $\mathrm{G}+\mathrm{C}$ in the 5 ' portion and the complicated secondary structure of the genomic RNA made it difficult to determine the complete sequence of this segment. In this study, reverse transcriptase that was stable at $65^{\circ} \mathrm{C}$ was used in 5' RACE to clone the 5' part of S4 genome segment. It was anticipated that NS88 was necessary to form viral inclusion bodies during virus infection, in which the virus genome replication and virion morphogenesis occurs. There were two coils (amino acid residues positions 587-635 and 700-762) in NS88, as predicted by Coils program. Sequence analysis also revealed that the corresponding NS88 proteins in Aquareovirus species all contained the two coils regions, and conserved histidine and cysteine.

The S5 genome segment was predicted to encode the minor core protein VP4, which is thought to be a nucleoside triphosphate phosphohydrolase as a putative cofactor of VP2. Amino acid sequence alignments showed two conserved lysine residues (positions 409 and 413) in SMReV VP4, which were also conserved in MRV, ARV, and Aquareovirus species except CHSRV.

The S6 genome segment was predicted to encode the outer capsid protein VP5. An autolytic cleavage site was predicted to be located between amino acid residues Asn42 and Pro43. In addition, a myristoylation consensus sequence, which is essential for the autolytic cleavage, was located in the N-terminus of VP5. Sequence alignment revealed that the N-terminal sequence of VP5 in aquareovirus species was highly conserved.

The S8 genome segment of SMReV was predicted to encode the core protein VP6. VP6 has an amino acids sequence identity of about $20 \%$ with the $\sigma 2$ protein of MRV species (Table 2). Secondary structure predictions revealed that a large number of $\beta$-sheets and turns existed in the $\mathrm{N}$-terminal portion (75\% of the protein) of SMReV VP6, which are characteristics of $\sigma 2 / \sigma \mathrm{A}$ proteins in MRV and ARV species $[18,19]$. However, there were some differences in the $\mathrm{C}$-terminal regions between SMReV VP6 and MRV $\sigma 2$, as revealed by hydrophobic analysis. Most of the amino acid residues in the C-terminal regions of VP6 are hydrophobic; however, they are hydrophilic in $\sigma 2$.

The S9 genome segment of SMReV was predicted to encode the nonstructural protein NS38. NS38 is thought to be involved in the formation of viral inclusion bodies with NS88. The amino acids sequence identity between NS38 and MRV $\sigma$ NS is lower than $20 \%$, but they show a high similarity in secondary structure and in their hydrophobicity.

The S10 genome segment of SMReV was predicted to encode the major outer capsid protein VP7. As the major outer capsid protein, VP7 had the most variability among aquareovirus species groups.

The S11 genome segment of SMReV was predicted to encode the nonstructural protein NS25. No equivalent proteins of NS25 were found in reovirus species other 
than aquareoviruses by BLAST analysis. An immunofluorescense assay showed that NS25 is distributed in the cytoplasm during $\mathrm{SMReV}$ infection (data not shown).

\section{Genome segment S7 encodes a FAST protein}

Initial ORF analysis by EditSeq in DNASTAR software showed that SMReV genome segment S7 contained only one ORF, which started from an AUG codon at nucleotide 489. However, except for CHSRV, the S7 segment in aquareoviruses usually contains more than one ORF. To determine the ORFs contained by SMReV S7, different recombinant plasmids that contained all or part of the S7 segment cDNA were constructed and expressed in fish cell lines. When the entire S7 segment cDNA was expressed, cultured fish cells formed syncytia in which the nucleus aggregated (Figure 3A-a). However, the expression of cDNA (489-1325, NS32) did not cause cell-cell fusion (Figure 3A-b). Cells expressing cDNA (1613) formed syncytia (Figure 3A-c). This indicated that the 5' part of the SMReV S7 segment encoded a protein that could cause cell-cell fusion and was translated from a non-AUG translation start site. Furthermore, expression of S7 cDNA (12-613) and cDNA (14-613) could induce cell-cell fusion (Figure $3 \mathrm{~B}$ ), but no cell-cell fusion occurred when cDNAs (15-613) and (19-613) were expressed. In addition, a point mutation at nucleotide $15\left({ }^{14} \mathrm{AUC}^{16}\right.$ to $\left.\mathrm{ACC}\right)$ did not influence the ability to form syncytia. However, syncytium formation was ablated by a point mutation at nucleotide $18\left({ }^{17} \mathrm{CUG}^{19}\right.$ to CCG) (Figure 3B). Considering the consensus sequence (RNNAUGG) of the non-AUG start site [20] and the sequence $\left({ }^{14} \mathrm{AUCCUGG}^{20}\right)$ near the nucleotide position 17 of S7 segment, it can be concluded that SMReV S7 segment encoded a protein from a CUG translation start site. This ORF starts from a CUG codon at nucleotides 17-19 and is terminated by UGA at nucleotides 611-613.

Thus, the S7 genome segment of SMReV contained more than one ORF. The first ORF encoded the FAST protein NS22 and the second ORF was predicted to encode a nonstructural protein, NS32.

\section{Fusogenic proteins in SMReV and GCRV}

In addition to NS22 of SMReV, the NS16 protein encoded by the first ORF (nucleotides positions 14-454) of the S7 genome segment of GCRV-873 was also identified here as a FAST protein. In vitro expression of NS16 in fish cells induced syncytium formation (Figure 3C-d). Expression of NS16-EGFP recombinant protein also induced syncytium formation, while NS16-EGFP was distributed in the fused cells (Figure 3C-e). Hydrophobic analysis by ProtScale (ExPASy Proteomics Server) revealed that NS22 and NS16 had a similar hydropathy profile (Figure 4A). However, there were some differences in the motifs contained in NS22 and NS16. A myristoylation consensus sequence (MGXXXS) was found in the N-terminus of NS22, but, surprisingly, no myristoylation site was predicted to exist in NS16. It had been reported that $\mathrm{N}$-terminal myristoylation was necessary for the fusion activity of reptilian reovirus (RRV) p14 protein [11]. NS22 and NS16 were both predicted to contain a transmembrane domain (TM, positions 35-57 for NS22 and 37-60 for NS16) by TMpred [21]. Following the TM domain, there are regions that contain a stretch of basic amino acid residues (PB) in both proteins (positions 61-68 and 82-95 for NS22 and 63-78 for NS16). The polybasic regions are thought to support the translocation of the N-terminal domain (34 amino acids for NS22 and 36 amino acids for NS16) into face the extracellular environment [11]. Besides the TM domain, another hydrophobic region, the hydrophobic patch $(\mathrm{PH})$, was predicted to exist in the $\mathrm{C}$-terminal fragment of both proteins (positions 140-150 for NS22 and 113119 for NS16). Moreover, there are two regions that are rich in arginine, proline, and histidine (RPH) in NS22 (Figure 4B). However, there are three RPH domains in the FAST protein of ASRV-2009 [12], despite its high sequence similarity with SMReV NS22.

\section{Comparison with other reovirus species and phylogenetic analysis}

Comparison of the electropherotype of SMReV in agarose gel electrophoresis with those reported from other aquareoviruses [22] revealed that the electropherotype of SMReV was similar to the members in AQRV-A. Interestingly, it was different to the electropherotype of TRV, which was isolated from turbot in Spain [23].

The genome sequence and deduced amino acids were compared to the sequences available from other aquareoviruses. SMReV had a larger M4 genome (2640 bp) segment than other sequenced aquareoviruses (GCRV/ GSRV, 2320 bp; AGCRV, 2293 bp). Overall identity values between SMReV and other aquareoviruses homologous proteins ranged from $13 \%$ to $94 \%$. The highest identity was between SMReV and species in AQRV-A, for example, CHSRV, which ranged from $76.2 \%$ to 92.8\%. However, the CHSRV genome sequence information lacked the complete M4 segment (Table 2).

The genes and proteins of SMReV were compared with their homologs from reovirus species other than aquareoviruses. The results showed that SMReV had a high similarity with species in Orthoreovirus (MRV and ARV, as shown in table 2). The highest amino acid sequence identities (40\%) between SMReV and Orthoreovirus species (MRV and ARV) were observed in the RNA-dependent RNA polymerase (VP2 in SMReV, $\lambda 3$ or $\lambda B$ in MRV and ARV species) (Table 2). A phylogenetic tree among 


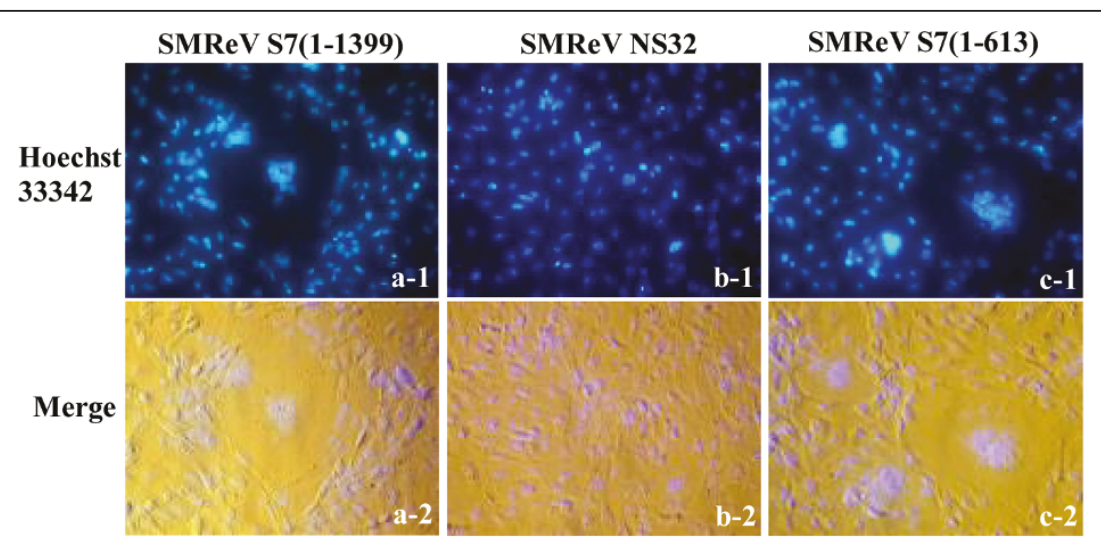

A
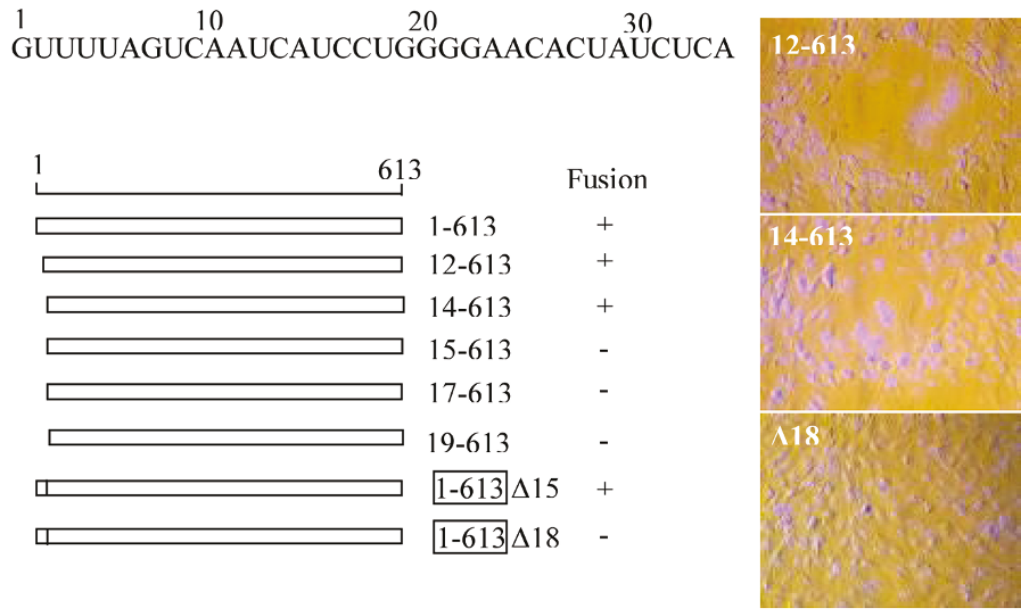

B
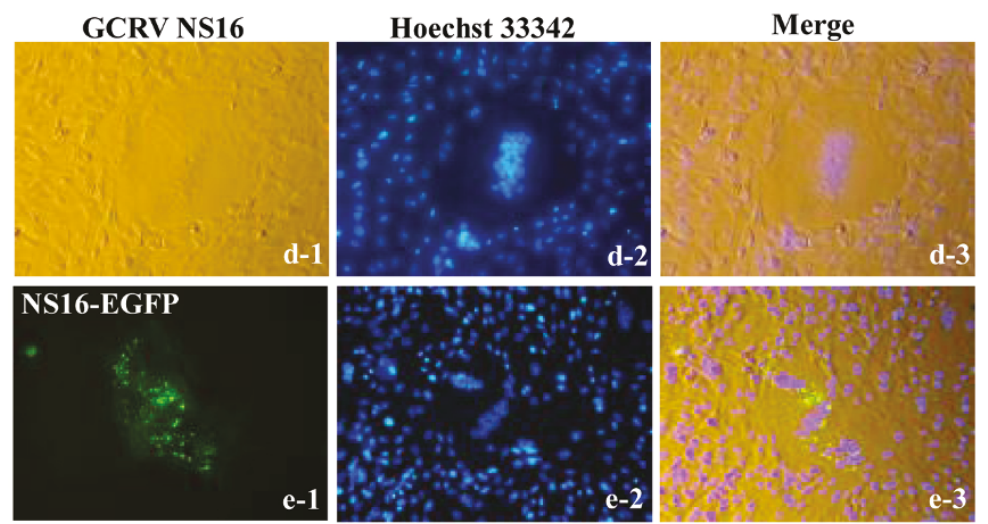

$\mathrm{C}$

Figure 3 FAST proteins encoded by SMReV and GCRV. (A) Genome segment S7 of SMReV encodes a FAST protein. CIK cells were transfected with plasmids expressing the full length, $5^{\prime}$ fragment (1-613), or NS32 of S7, respectively. Expression of full length or $5^{\prime}$ fragment (1-613) of S7 induced syncycium formation (panel a 1-2 and panel c 1-2), but no syncycium formation was observed in cells expressing NS32 (panel b 1-2). (B) Determining the translation start site of NS22. The $5^{\prime}$ terminal sequence of S7 is shown at top of the figure. The $5^{\prime}$ fragment of S7 is schematically indicated by a horizontal line comprising bases 1-613 (positions numbered on the top). A similar horizontal bar indicates each truncation or mutation. The ability of each construct to form a syncytium is indicated as positive (+) or negative (-). Representative images of transfected CIK cells are presented at the right side of the figure. (C) Cell-cell fusion induced by NS16 encoded by S7 of GCRV. CIK cells were transfected with plasmid pcDNA3.1-NS16 and pEGFP-NS16 respectively. 


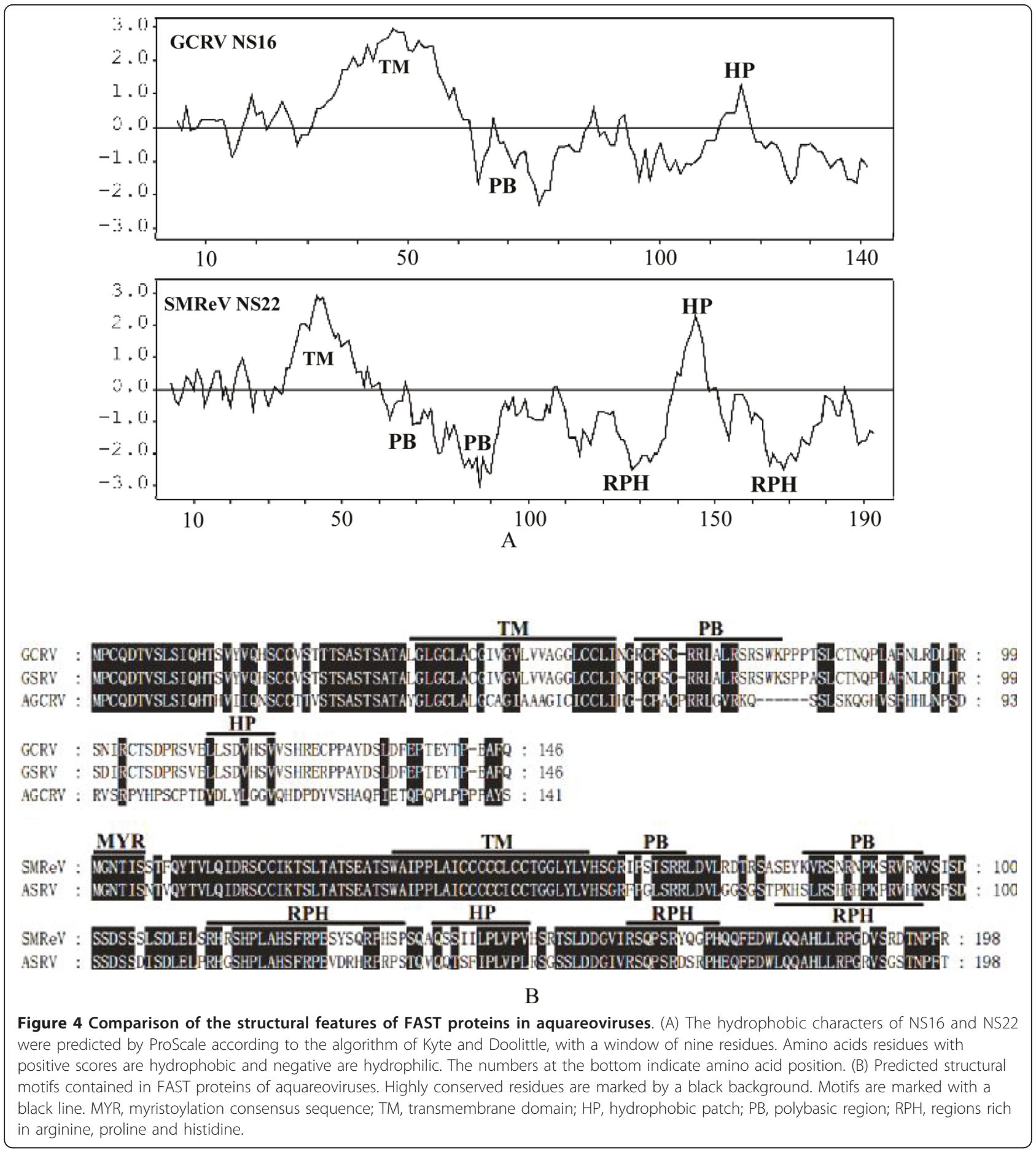

members of fourteen genera of Reoviridae, for whom sequence information was available, was constructed based on the RdRp sequences (Figure 5A). The genus Aquareovirus was clustered more closely with the Orthoreovirus. Interestingly, as shown in Figure 5A, several genus groups that have different genome segments numbers and hosts have a relatively close evolutionary relationship. For example, members from the genus Cardoreovirus and Seadornavirus were closely clustered. Members from the genus Cypovirus and Dinovernavirus were also closely clustered. In addition, there were two subfamilies in Reoviridae: Spinareovirinae and Sedoreovirinae. Members in Spinareovirinae are turreted reoviruses, which have turrets situated on the virus core 


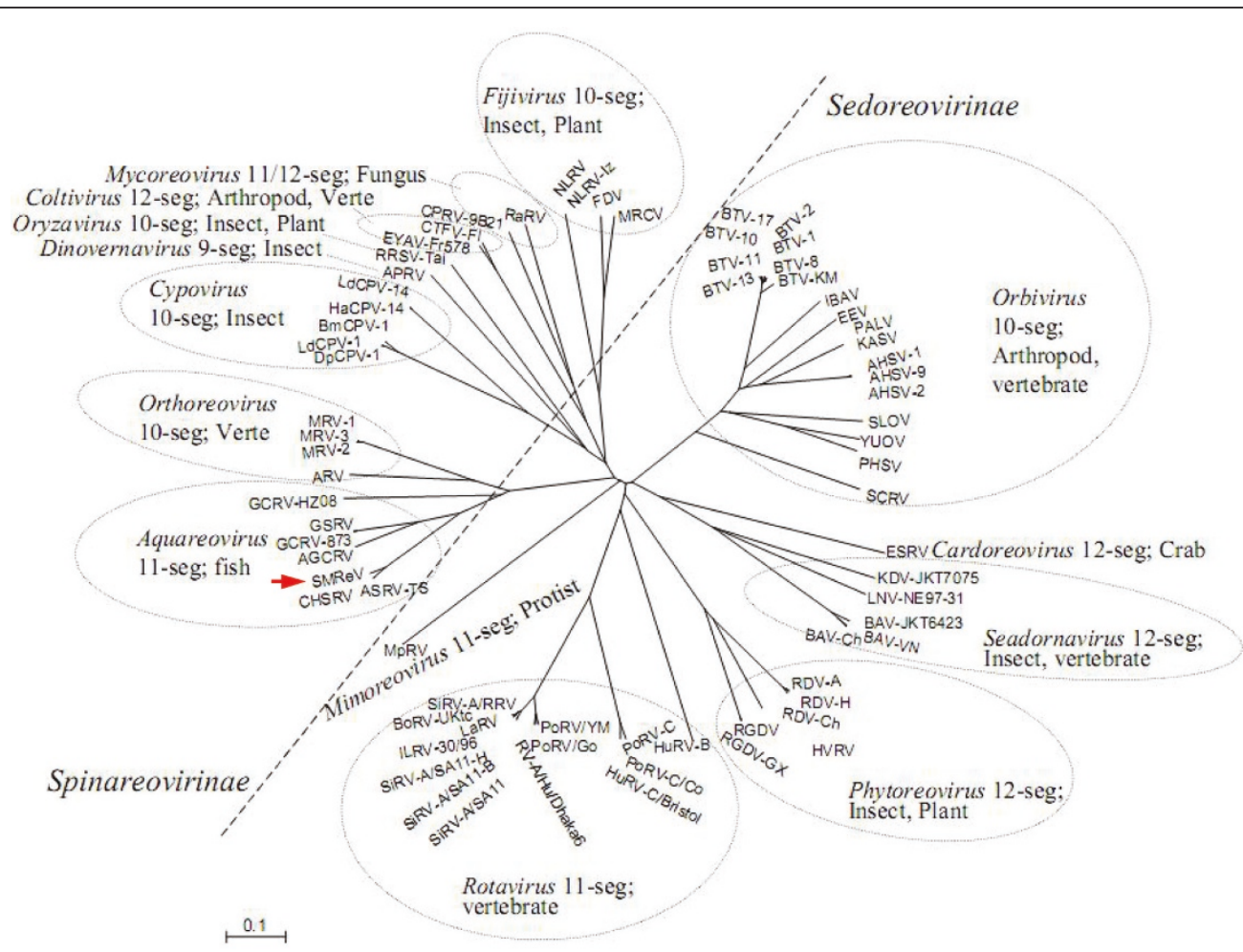

A

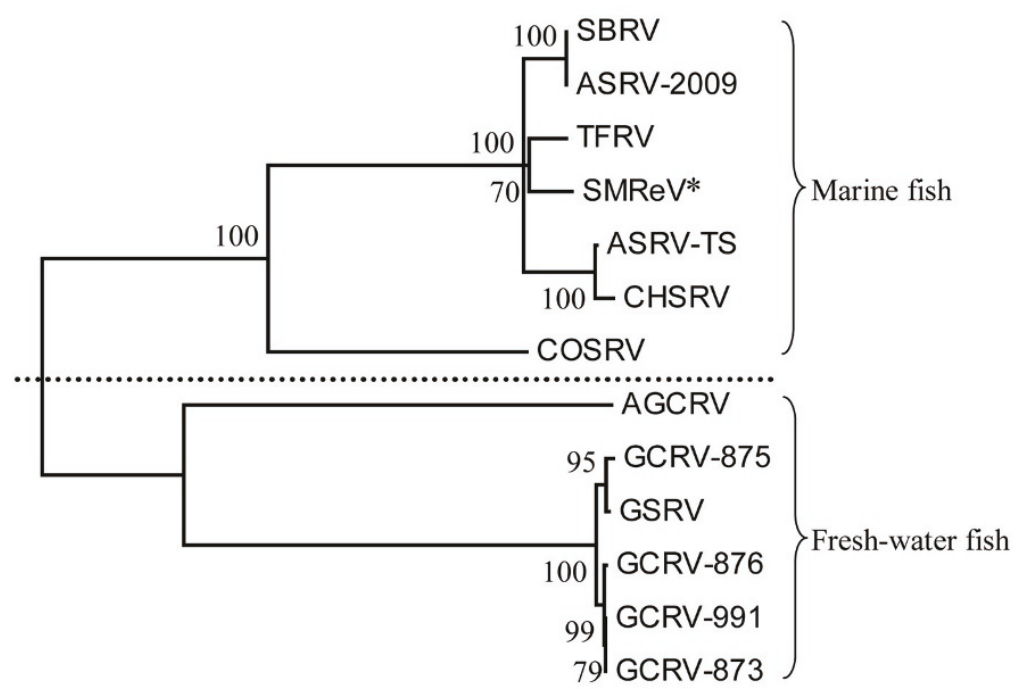

0.2

B

Figure 5 Phylogenetic analysis. (A) The phylogenetic analysis based on the RNA dependent RNA polymerase of Reoviridae. The phylogenetic tree was constructed using the neighbor-joining method in MEGA 4.0. Numbers of the genome segments and hosts of each genus are shown. Two subfamilies, Spinareovirinae and Sedoreovirinae, were divided by a skewed broken line. (B) The phylogenetic analysis of the major outer capsid protein VP7 from aquareovirus species was carried out as in materials and methods. The numbers given are frequencies (\%) at which a given branch appeared in 1000 bootstrap replications. Viruses appearing above the broken line are from hosts that had seawater life-histories and viruses from hosts that lived in fresh water are listed below the broken line. GenBank accession numbers were collected in additional file 2 and 3 . 
structure. Members in Sedoreovirinae are non-turreted reoviruses. Two large species groups also existed in the present phylogenetic analysis. On the left side of Figure 5A (divided by a skewed line), are members in Spinareovirinae. Members in Sedoreovirinae are clustered on the right side of Figure 5A.

As the viral major outer capsid protein, VP7 is the most variable protein in aquareoviruses. A phylogenetic tree was constructed with VP7 amino acid sequences in aquareoviruses. It showed that $\mathrm{SMReV}$ was most related to viruses in AQRV-A (SBRV, striped bass reovirus; ASRV; CHSRV; TFRV, threadfin reovirus) (Figure 5B). Interestingly, the viruses from hosts that had a seawater life history were closely related (above the broken line in Figure 5B), and were different from those whose hosts lived in fresh water (below the broken line in Figure 5B).

The phylogenetic information has been deposited in the TreeBASE database under access URL: http://purl. org/phylo/treebase/phylows/study/TB2:S11304.

\section{Discussion}

\section{Putative functions of proteins revealed by motif comparison}

It has been reported that the four conserved amino acids (two lysines and two histidines) in VP1 are essential amino acids for the guanylyltransferase activity of the homologous proteins in MRV, ARV (avian orthoreovirus), and GCRV [24-26]. Several functional domains were also identified in GCRV VP1 by CryoEM analysis, such as the GTPase domain, the methyltransferase domain, and the immunoglobulin domain [17].

The two lysine residues in VP4 are essential for ATPase activity in homologous protein $\mu \mathrm{A}$ of ARV [27]. By comparison with the proteins from MRV and ARV, VP4 was thought to be a nucleoside triphosphate phosphohydrolase and a putative cofactor of VP2.

The autolytic cleavage site, Asn42 and Pro43, which allowed the protein to be cleaved during virus infection to produce an $\mathrm{N}$-terminal fragment and a $\mathrm{C}$-terminal fragment [28], was identified as SMReV VP5. Previous research reported that VP5 and VP7 formed heterodimers to form the outer capsid in GCRV [29]. In the early stage of infection, the outer capsid is proteolytically cleaved and disassembled to form the infectious subviral particles (ISVPs), which have enhanced infectivity [30].

Viral inclusions, or viral factories, are formed in the cytoplasm during reovirus infection. It has been reported that MRV nonstructural proteins $\mu \mathrm{NS}$ and $\sigma \mathrm{NS}$ form viral inclusion bodies in vivo and in vitro [31,32]. Based on sequence comparisons, it was anticipated that $\mathrm{SMReV}$ NS88 had a function in forming viral inclusions along with NS38. The two coils structure in NS88 was thought to be essential for viral inclusions formation. Conserved histidines and cysteines between the two coil regions are also important for inclusion formation in MRV and ARV $[33,34]$. In addition, the $\mathrm{N}$-terminal amino acid residues in NS38 were predicted to form an alpha-helix, which could be important for nucleoprotein complex formation in the $\sigma \mathrm{NS}$ protein [35].

Moreover, the second ORF of S7 segment in MRV encodes the $\sigma \mathrm{C}$ protein, which is a structural protein and is involved in cell attachment [36]. However, the protein corresponding to $\sigma \mathrm{C}$ in Aquareovirus species is a nonstructural protein [29].

\section{FAST proteins of aquareoviruses with different translation} start sites

Sequence and structural analysis agreed with the previous report that there were two types of FAST proteins in aquareoviruses [12]. One type comprises the NS16 proteins encoded by GCRV, GSRV (AQRV-C), and AGCRV (AQRV-G). The other type comprises the NS22 proteins encoded by SMReV and ASRV-2009 (AQRV-A). The FAST proteins of SMReV and ASRV-2009 use a noncanonical translation start site. There are some differences in the motifs in the two types of FAST proteins (Figure $4 \mathrm{~B})$. Racine et al. reported that NS16 could be a homolog of the reptilian orthoreovirus (RRV) p14 FAST protein. However, p14 contains an N-terminal myristoylation site that is essential for fusion activity [11]. Sequence analysis found no N-terminal myristoylation site in NS16. This indicated that NS16 could not be a homolog of RRV p14. The sequence comparison also showed that the motif and structural arrangements of NS16 were more similar with ARV p10 FAST protein [9]. Further analysis of the functions of each motif could facilitate the understanding of the mechanisms involved in syncytium formation and the evolution of FAST proteins.

Non-AUG translation start codons have been reported in many organisms, including viruses [20,37], such as the Sendai virus [38] and the Moloney murine leukemia virus (MoMuLV) [39]. Recently, a CUG start codon was identified in ASRV-2009, which was utilized for translating a FAST protein [12]. The non-canonical start site (CUG in SMReV and ASRV-2009) used in FAST proteins could be a strategy by which the translation efficiency is regulated. Inefficient expression of FAST proteins could reduce the rate of cell-cell fusion and facilitate the production of viral progeny. In addition, the start codon of the FAST protein of GCRV (NS16) is AUG; however, the nucleotide sequence around this AUG site (ACCAUGC) did not accord with the Kozak consensus sequence (G/ ANNAUGG). This also indicated that NS16 could be translated with relatively low efficiency.

\section{Taxonomic status of SMReV and evolution analysis}

Aquareoviruses have been divided into seven Aquareovirus species groups (AQRV-A to AQRV-G) [3,4]. The division 
of the different Aquareovirus species groups was based on electropherotype, serological comparison, the ability to reassort during mixed infections, conserved terminal sequences, and RNA sequence analyses. Genome electrophoresis, and gene and protein comparison revealed that SMReV could be a member of species group AQRV-A. Interestingly, turbot reovirus (TRV), which was isolated from Spain, was classified in species group AQRV-E by RNA-RNA hybridization [23].

Phylogenetic analysis indicated that the evolution of VP7 was affected by selective pressure from the host organisms. Evolution of aquareoviruses was closely related to the environment in which the host organisms lived. The family Reoviridae contains a large number of members that infect vertebrates, invertebrates, plants, and fungi. Members in Aquareovirus and Orthoreovirus have a common evolutionary origin with those from Mycoreovirus and Coltivirus, Cypovirus, and Dinovernavirus. It is interesting that viruses from vertebrates and fungi have a common ancestor. These genera comprise viruses that have genome segments ranging from 9 to 12. It has been speculated that reoviruses diverged from a common ancestor may have gained or lost a genome segment that was required or not in different hosts during the course of evolution [40]. In this case, the S11 segment in Aquareovirus species that has no equivalent in Orthoreovirus may be involved in virus-host interactions. Moreover, the model of genetic "jump", which involves changes in the number of genome segments, has been reported between the rotaviruses and the seadornaviruses, and between the aquareoviruses and the coltiviruses [4,41]. This model involves a process in which a single segment undergoes duplication and deletion to generate two separate segments. In this case, the S7 segment of aquareoviruses corresponds to segments 9 and 12 of coltiviruses.

\section{Conclusions}

In summary, the present study provided the complete genome sequence of a newly isolated turbot reovirus from China. It is the first complete sequence of an aquareovirus from marine fish. Amino acids comparison and phylogenetic analysis suggested that SMReV is a new aquareovirus in the species group Aquareovirus A. Phylogenetic relationships among aquareoviruses revealed that VP7 could be used as a reference to divide the aquareovirus from freshwater hosts from those from marine hosts. Based on the complete genome sequence, a FAST protein with a non-AUG start site was identified, which partially contributed to the cytopathic effect caused by viral infection. These results provide new insights into the virus-host or virus-environment interactions.

\section{Methods}

\section{Original viral isolate preparation}

Diseased cultured turbot Scophthalmus maximus were sampled from a fish farm in Shandong province of northern China. The original viral isolate was prepared from tissues (liver, kidney, and spleen) of these fish as described previously [42]. Briefly, tissues were cut into pieces and homogenized in phosphate-buffered saline (PBS) containing antibiotics (penicillin, $100 \mathrm{IU} \mathrm{ml}^{-1}$; streptomycin, $100 \mathrm{IU} \mathrm{ml}^{-1}$ ). Extracts were filtered through a 45 um filter membrane and stored at $-80^{\circ} \mathrm{C}$ as the original viral isolate for cell infections.

\section{Cell culture and virus infection}

Chinook salmon embryo (CHSE), Flounder embryo (FE), Epithelioma papulosum cyprini (EPC), and GCF cell lines, were used for viral isolation and sensitivity tests. Tissue lysates acquired above were inoculated into confluent monolayers of these cells in 199 medium supplemented with $10 \%$ fetal bovine serum at $15^{\circ} \mathrm{C}, 20^{\circ} \mathrm{C}$ or $25^{\circ} \mathrm{C}$.

Grass carp reovirus 873 (GCRV-873) used in this study was maintained in our laboratory [43]. Ctenopharyngodon idellus kidney (CIK) cells were used for GCRV873 propagation at $25^{\circ} \mathrm{C}$.

\section{Biophysical and biochemical property detection}

The optimal temperature for virus propagation was assayed by infection of monolayers of GCF cell cultures at $15^{\circ} \mathrm{C}, 20^{\circ} \mathrm{C}$, or $25^{\circ} \mathrm{C}$. Heat stability was measured by incubating the virus suspension at $56^{\circ} \mathrm{C}$ or $60^{\circ} \mathrm{C}$ for 30 min, or $60 \mathrm{~min}$ and then the titer was determined. Chloroform and 5-iodo-2'-deoxyuridine sensitivity was determined as described previously [44].

\section{Virus isolation and purification}

Infected GCF cells were harvested at five days post infection and centrifuged at $8,000 \mathrm{~g}$ for $30 \mathrm{~min}$ at $4^{\circ} \mathrm{C}$. The supernatant was then ultracentrifuged at 32,000 rpm (Beckman rotor SW41) for $90 \mathrm{~min}$. The virus pellet was resuspended in $1.5 \mathrm{ml} 0.1 \mathrm{M}$ Tris- $\mathrm{Cl}(\mathrm{PH} 8.6)$ and further purified by discontinuous sucrose $(20 \% 30 \%, 40 \%$, $50 \%$, and $60 \%, \mathrm{w} / \mathrm{v}$ ) gradient centrifugation at 30,000 $\mathrm{rpm}$ for $60 \mathrm{~min}$. The virus particle band was collected and sucrose was removed by centrifugation at 32, 000 $\mathrm{rpm}$ for $90 \mathrm{~min}$ in $0.1 \mathrm{M}$ Tris- $\mathrm{Cl}$ ( $\mathrm{PH} \mathrm{8.6)}$. The resulting pellet was resuspended in $0.2 \mathrm{ml} 0.1 \mathrm{M}$ Tris- $\mathrm{Cl}(\mathrm{PH} 8.6)$ and stored at $-20^{\circ} \mathrm{C}$ until use.

\section{Electron microscopy}

Purified virus particles were negatively stained with $2 \%$ $(\mathrm{w} / \mathrm{v})$ uranylacetate and then examined with transmission electron microscopy (JEM-1230). 


\section{Virus dsRNA preparation and cloning}

Virus dsRNA was extracted from purified virus particles using Trizol Reagent (Invitrogen) following the manufacturer's protocols. Synthesis of cDNA from SMReV dsRNA was carried out using the single-primer amplification technique $[45,46]$. Briefly, an oligodeoxyribonucleotide primer, TC1 (5' $\mathrm{PO}_{4}$-CCCGCCATCCTCACTTAGACT-NH ${ }_{2}$ 3') was ligated to both of the 3' ends of the dsRNA segments using T4 RNA ligase (Takara). dsRNA was denatured at $94^{\circ} \mathrm{C}$ for $5 \mathrm{~min}$ in the presence of $15 \%$ DMSO before being cooled rapidly on ice. cDNA synthesis was then carried out in a cDNA reaction using M-MLV (Promega). RNA was then removed by adding $\mathrm{NaOH}$ and the cDNA was annealed at $65^{\circ} \mathrm{C}$ overnight. After purification through a Sephacryl S-400 spin column (Promega), the cDNA was amplified by PCR using the primer TC2 (5' AGTCTAAGTGAGGATGGCGGG 3') with following cycles: 2 min elongation at $72^{\circ} \mathrm{C} ; 94^{\circ} \mathrm{C}$ for $5 \mathrm{~min}$; followed by 32 cycles of amplification $\left(94^{\circ} \mathrm{C}\right.$ for $30 \mathrm{~s}, 55^{\circ} \mathrm{C}$ for $30 \mathrm{~s}, 72^{\circ} \mathrm{C}$ for $3 \mathrm{~min}$ ).

To clone the 5' parts of the S4 segment, cDNA was synthesized using a primer designed from the partial sequence obtained above, as described previously [47]. Reverse transcription was carried out using ThermoScript reverse transcriptase (Invitrogen). The resulting cDNA was purified and poly $(C)$ tailed by terminal deoxynucleotidyl transferase (TDT, Takara). First round PCR was performed using primers designed above and 5' AP. The second round PCR was carried out using internal primers and 5' UP (see additional file 1).

\section{Sequencing and sequence analysis}

PCR products were separated on a 1\% agarose gel and all visible bands were purified and cloned into the pMD18$\mathrm{T}$ vector (Takara). The positive clones were sequenced.

Aquareoviruses and other reoviruses sequences were obtained from the GenBank (NCBI). The accession numbers were collected in additional file 2. Nucleotide sequences and deduced amino acid sequences were analyzed using the EditSeq program (DNASTAR, USA). Multiple sequence alignments were conducted using the Clustal $\times 1.83$ program. Sequence identities were calculated using the Clusta W method in the MegAlign program. Neighbor-joining phylogenetic trees were constructed using the Poisson correction models with 1000 bootstrap replicates in MEGA 4.0 [48]. Hydrophobicity plots of proteins were predicted using ProtScale (ExPASy) with the Kyte and Doolittle algorithm [49]. The coils program [50] was employed to predict coiled regions in SMReV protein.

\section{Plasmid construction}

Genome segment S7 of SMReV was amplified from cDNAs obtained above using primers S7-F/R. The PCR products were digested with EcoR I and Xho I, and then ligated into vector pcDNA3.1(+) that had been digested with the same enzymes, which resulted in the recombinant plasmid pcDNA3.1-S7. To generate recombinant plasmids that contained truncations or mutations in the 5' portions of SMReV S7 segment, PCR primers that used pcDNA3.1-S7 as a template were designed and appear in Additional file 1. PCR products were cut and ligated into pcDNA3.1(+) vector with corresponding enzymes. NS32 of SMReV was also cloned into pcDNA3.1(+) using the same methods and primers NS32-F/S7-R.

To generate recombinant plasmid pcDNA3.1-NS16 and pEGFP-NS16, GCRV genomic dsRNA was used as template for RT-PCR. dsRNA of GCRV was reverse transcribed using the method described above. cDNA products were used in a PCR reaction to amplify NS16 using primers NS16-F/R or N3-NS16-F/R (Additional file 1), respectively. PCR products were cut and ligated into pcDNA3.1(+) or pEGFP-N3 with corresponding restriction enzymes.

All constructs were confirmed by DNA sequencing.

\section{Transfection and cell staining}

CIK cells were seeded into 24-well or 6-well cell culture plates using 199 medium containing $5 \%$ of FBS for $24 \mathrm{~h}$ before transfection. Cells were transfected with plasmids using Lipofectamine 2000 (Invitrogen, U.S.A.) following the manufacturer's protocol.

Transfected cells were incubated $24 \mathrm{~h}$ at $25^{\circ} \mathrm{C}$ and then fixed and stained with Hoechst 33342 as described previously [51]. All samples were examined under a Leica DM IRB fluorescence microscope.

\section{Nucleotide sequence accession number}

The GenBank/EMBL/DDBJ accession numbers for the sequences reported here are: HM989930-HM989940.

\section{Additional material}

Additional file 1: Primer sequences used in $5^{\prime}$ RACE and plasmids construction

Additional file 2: GenBank accession numbers of the aquareovirus and orthoreovirus genome sequences from this study.

Additional file 3: GenBank accession numbers of the RNA

dependent RNA polymerase in the family Reoviridae.

\section{Acknowledgements and Funding}

This work was supported by grants from the National Major Basic Research Program (2009CB118704, 2010CB126300), the National Natural Science Foundation of China $(30871938,31072239)$, the Knowledge Innovation Program of the Chinese Academy of Sciences (KSCX2-EW-Z-3), the Special Fund for Agro-scientific Research in the Public Interest (200803013), and the Project of State Key Laboratory of Freshwater Ecology and Biotechnology (O85B16-1-F01). 


\section{Authors' contributions}

ZQY designed the project; $\mathrm{KF}$ performed the experiments and analyzed the data; HLB and PC participated in PCR amplification and gene cloning; and $\mathrm{KF}$ and ZQY wrote the article. All authors read and approved the final manuscript.

Received: 3 November 2010 Accepted: 20 June 2011

Published: 20 June 2011

\section{References}

1. Lupiani B, Subramanian K, Samal SK: Aquareoviruses. Annual review of Fish Diseases 1995, 5:175-208.

2. Seng EK, Fang Q, Chang SF, Ngoh GH, Qin QW, Lam TJ, Sin YM: Characterisation of a pathogenic virus isolated from marine threadfin fish (Eleutheronema tetradactylus) during a disease outbreak. Aquaculture 2002, 214:1-18.

3. Samal SK, Attoui H, Mohd Jaafar F, Mertens PPC: Aquareovirus, Reoviridae. In Virus Taxonomy. Eighth Report of the International Committee on Taxonomy of Viruses. Edited by: Fauquet CM, Mayo MA Maniloff J, Desselberger U, Ball LA. London: Elsevier/Academic press; 2005:511-516.

4. Mohd Jaafar F, Goodwin AE, Belhouchet M, Merry G, Fang Q, Cantaloube JF, Biagini P, de Micco P, Mertens PP, Attoui H: Complete characterisation of the American grass carp reovirus genome (genus Aquareovirus: family Reoviridae) reveals an evolutionary link between aquareoviruses and coltiviruses. Virology 2008, 373:310-321.

5. Fang $Q$, Attoui H, Cantaloube JF, Biagini $P$, Zhu Z, de Micco P, de Lamballerie $X$ : Sequence of genome segments 1,2 and 3 of the grass carp reovirus (Genus Aquareovirus, family Reoviridae). Biochem Biophys Res Commun 2000, 274:762-766.

6. Attoui H, Fang Q, Mohd Jaafar F, Cantaloube JF, Biagini P, de Micco P, de Lamballerie $X$ : Common evolutionary origin of aquareoviruses and orthoreoviruses revealed by genome characterization of Golden shiner reovirus, Grass carp reovirus, Striped bass reovirus and golden ide reovirus (genus Aquareovirus, family Reoviridae). J Gen Virol 2002, 83:1941-1951.

7. Duncan R, Chen Z, Walsh S, Wu S: Avian reovirus-induced syncytium formation is independent of infectious progeny virus production and enhances the rate, but is not essential, for virus-induced cytopathology and virus egress. Virology 1996, 224:453-464.

8. Duncan R: Extensive sequence divergence and phylogenetic relationships between the fusogenic and nonfusogenic orthoreoviruses: a species proposal. Virology 1999, 260:316-328.

9. Shmulevitz M, Duncan R: A new class of fusion-associated small transmembrane (FAST) proteins encoded by the non-enveloped fusogenic reoviruses. EMBO J 2000, 19:902-912.

10. Dawe $S$, Duncan R: The $S 4$ genome segment of baboon reovirus is bicistronic and encodes a novel fusion-associated small transmembrane protein. J Virol 2002, 76:2131-2140.

11. Corcoran JA, Duncan R: Reptilian reovirus utilizes a small type III protein with an external myristylated amino terminus to mediate cell-cell fusion. J Virol 2004, 78:4342-4351.

12. Racine T, Hurst T, Barry C, Shou J, Kibenge F, Duncan R: Aquareovirus effects syncytiogenesis by using a novel member of the FAST protein family translated from a noncanonical translation start site. J Virol 2009, 83:5951-5955.

13. Zhang C, Wang $Q$, Shi C, Zeng W, Liu Y, Wu S: Molecular analysis of grass carp reovirus HZ08 genome segments 1-3 and 5-6. Virus Genes 2010, 41:102-104.

14. Xu ZK, Anzola JV, Nalin CM, Nuss DL: The 3'-terminal sequence of a wound tumor virus transcript can influence conformational and functional properties associated with the $5^{\prime}$-terminus. Virology 1989, 170:511-522.

15. Patton JT: Rotavirus RNA replication and gene expression. Novartis Found Symp 2001, 238:64-77.

16. O'Reilly EK, Kao CC: Analysis of RNA-dependent RNA polymerase structure and function as guided by known polymerase structures and computer predictions of secondary structure. Virology 1998, 252:287-303.

17. Cheng L, Zhu J, Hui WH, Zhang X, Honig B, Fang Q, Zhou ZH: Backbone model of an aquareovirus virion by cryo-electron microscopy and bioinformatics. J Mol Biol 2010, 397:852-863.
18. Dermody TS, Schiff LA, Nibert ML, Coombs KM, Fields BN: The S2 gene nucleotide sequences of prototype strains of the three reovirus serotypes: characterization of reovirus core protein sigma 2. J Virol 1991, 65:5721-5731.

19. Thalmann CM, Cummins DM, Yu M, Lunt R, Pritchard LI, Hansson E, Crameri S, Hyatt A, Wang LF: Broome virus, a new fusogenic Orthoreovirus species isolated from an Australian fruit bat. Virology 2010, 402:26-40.

20. Kozak M: Structural features in eukaryotic mRNAs that modulate the initiation of translation. J Biol Chem 1991, 266:19867-19870.

21. Hofmann K, Stoffel W: TMbase-A database of membrane spanning proteins segments. Biol Chem Hoppe-Seyler 1993, 374:166.

22. Samal SK, Dopazo CP, Subramanian K, Lupiani B, Mohanty SB, Hetrick FM: Heterogeneity in the genome RNAs and polypeptides of five members of a novel group of rotavirus-like viruses isolated from aquatic animals. $J$ Gen Virol 1991, 72:181-184.

23. Lupiani B, Dopazo CP, Ledo A, Fouz B, Barja JL: New Syndrome of Mixed Bacterial and Viral Etiology in Cultured Turbot Scophthalmus maximus. J Aquat Anim Health 1989, 1:197-204.

24. Luongo CL, Reinisch KM, Harrison SC, Nibert ML: Identification of the guanylyltransferase region and active site in reovirus mRNA capping protein lambda2. J Biol Chem 2000, 275:2804-2810.

25. Hsiao J, Martínez-Costas J, Benavente J, Vakharia VN: Cloning, expression, and characterization of avian reovirus guanylyltransferase. Virology 2002, 296:288-299.

26. Qiu T, Luongo CL: Identification of two histidines necessary for reovirus mRNA guanylyltransferase activity. Virology 2003, 316:313-324.

27. Su YP, Shien JH, Liu HJ, Yin HS, Lee LH: Avian reovirus core protein muA expressed in Escherichia coli possesses both NTPase and RTPase activities. J Gen Virol 2007, 88:1797-1805.

28. Zhang $X$, Jin L, Fang $Q$, Hui WH, Zhou ZH: 3.3 A cryo-EM structure of a nonenveloped virus reveals a priming mechanism for cell entry. Cell 2010, 141:472-482

29. Cheng L, Fang Q, Shah S, Atanasov IC, Zhou ZH: Subnanometer-resolution structures of the grass carp reovirus core and virion. J Mol Biol 2008, 382:213-222.

30. Fang Q, Seng EK, Ding QQ, Zhang LL: Characterization of infectious particles of grass carp reovirus by treatment with proteases. Arch Virol 2008, 153:675-682

31. Miller CL, Broering TJ, Parker JS, Arnold MM, Nibert ML: Reovirus sigma NS protein localizes to inclusions through an association requiring the $\mathrm{mu}$ NS amino terminus. J Virol 2003, 77:4566-4576.

32. Becker MM, Peters TR, Dermody TS: Reovirus sigma NS and mu NS proteins form cytoplasmic inclusion structures in the absence of viral infection. J Virol 2003, 77:5948-5963.

33. Kobayashi T, Ooms LS, Chappell JD, Dermody TS: Identification of functional domains in reovirus replication proteins muNS and mu2. $J$ Virol 2009, 83:2892-2906.

34. Brandariz-Nuñez A, Menaya-Vargas R, Benavente J, Martinez-Costas J: Avian reovirus microNS protein forms homo-oligomeric inclusions in a microtubule-independent fashion, which involves specific regions of its C-terminal domain. J Virol 2010, 84:4289-4301.

35. Gillian AL, Nibert ML: Amino terminus of reovirus nonstructural protein sigma NS is important for ssRNA binding and nucleoprotein complex formation. Virology 1998, 240:1-11.

36. Kirchner E, Guglielmi KM, Strauss HM, Dermody TS, Stehle T: Structure of reovirus sigma1 in complex with its receptor junctional adhesion molecule-A. PLoS Pathog 2008, 4:e1000235.

37. Murcia-Flores L, Lorca-Pascual JM, Garre V, Torres-Martínez S, RuizVázquez RM: Non-AUG translation initiation of a fungal RING finger repressor involved in photocarotenogenesis. J Biol Chem 2007, 282:15394-15403.

38. Curran J, Kolakofsky D: Ribosomal initiation from an ACG codon in the Sendai virus P/C mRNA. EMBO J 1988, 7:245-251.

39. Prats $A C$, De Billy G, Wang P, Darlix JL: CUG initiation codon used for the synthesis of a cell surface antigen coded by the murine leukemia virus. J Mol Biol 1989, 205:363-372.

40. Suzuki N, Supyani S, Maruyama K, Hillman Bl: Complete genome sequence of Mycoreovirus-1/Cp9B21, a member of a novel genus within the family Reoviridae, isolated from the chestnut blight fungus Cryphonectria parasitica. J Gen Virol 2004, 85:3437-3448. 
41. Mohd Jaafar F, Attoui $H$, Mertens PP, de Micco P, de Lamballerie X: Structural organization of an encephalitic human isolate of Banna virus (genus Seadornavirus, family Reoviridae). J Gen Virol 2005, 86:1147-1157.

42. Zhang QY, Tao JJ, Gui L, Zhou GZ, Ruan HM, Li ZQ, Gui JF: Isolation and characterization of Scophthalmus maximus rhabdovirus. Dis Aquat Organ 2007, 74:95-105.

43. Zhang QY, Ruan HM, Li ZQ, Zhang J, Gui JF: Detection of grass carp hemorrhage virus (GCHV) from Vietnam and comparison with GCHV strain from China. Chinese High Technology Letters 2003, 9:7-13.

44. Zhang QY, Li ZQ, Gui JF: Isolation of a lethal rhabdovirus from the cultured Chinese sucker Myxocyprinus asiaticus. Dis Aquat Organ 2000, 42:1-9.

45. Lambden PR, Cooke SJ, Caul EO, Clarke IN: Cloning of noncultivatable human rotavirus by single primer amplification. J Virol 1992, 66:1817-1822.

46. Attoui $H$, Billoir F, Cantaloube JF, Biagini $P$, de Micco P, de Lamballerie $X$ : Strategies for the sequence determination of viral dsRNA genomes. $J$ Virol Methods 2000, 89:147-158.

47. Tao JJ, Zhou GZ, Gui JF, Zhang QY: Genomic sequence of mandarin fish rhabdovirus with an unusual small non-transcriptional ORF. Virus Res 2008, 132:86-96.

48. Tamura K, Dudley J, Nei M, Kumar S: MEGA4: Molecular Evolutionary Genetics Analysis (MEGA) software version 4.0. Mol Biol Evol 2007, 24:1596-1599.

49. Kyte J, Doolittle RF: A simple method for displaying the hydropathic character of a protein. J Mol Biol 1982, 157:105-132.

50. Lupas A, Van Dyke M, Stock J: Predicting Coiled Coils from Protein Sequences. Science 1991, 252:1162-1164.

51. Ke F, Zhao Z, Zhang QY: Cloning, expression and subcellular distribution of a Rana grylio virus late gene encoding ERV1 homologue. Mol Biol Rep 2009, 36:1651-1659.

doi:10.1186/1471-2164-12-323

Cite this article as: Ke et al: Turbot reovirus (SMReV) genome encoding

a FAST protein with a non-AUG start site. BMC Genomics 2011 12:323.

\section{Submit your next manuscript to BioMed Central and take full advantage of:}

- Convenient online submission

- Thorough peer review

- No space constraints or color figure charges

- Immediate publication on acceptance

- Inclusion in PubMed, CAS, Scopus and Google Scholar

- Research which is freely available for redistribution

Submit your manuscript at www.biomedcentral.com/submit 